J. Clin. Chem. Clin. Biochem.

Vol. 18, 1980, pp. 345-349

\title{
Superiority of ABTS over Trinder Reagent as Chromogen in Highly Sensitive Peroxidase Assays for Enzyme Linked Immunoadsorbent Assay
}

\author{
By N. P. Groome \\ Department of Biology, Oxford Polytechnic, Headington, Oxford OX3 OBP, UK
}

(Received October 10, 1979/January 15, 1980)

Summary: Most of the currently used enzyme immunological assays employ horse radish peroxidase as marker enzyme. A comparison is presented of ABTS (2,2'-azino-di-(3-ethyl benzthiazoline-6-sulphonic acid) and the Trinder reagent as chromogens for the detection of small amounts of solid phase peroxidase.

The formation of chromophore using the Trinder reagent under the conditions described by Gallati (J. Clin. Chem. Clin. Biochem. (1977) 15, 699-703) reaches a plateau after 3-4 h due to $\mathrm{H}_{2} \mathrm{O}_{2}$ induced inactivation of the enzyme.

In contrast, with suitable temperature and concentrations of $\mathrm{H}_{2} \mathrm{O}_{2}$ and $\mathrm{ABTS}$, chromophore production continues in this system for at least $20 \mathrm{~h}$.

In an Enzyme Linked Immunoadsorbent Assay for antibodies to myelin basic protein the use of the ABTS/ $\mathrm{H}_{2} \mathrm{O}_{2}$ substrate system described here gives an assay 14 times more sensitive than the maximum possible with Trinder reagent.

\section{Überlegenheit von ABTS über Trinder's Reagenz als Chromogen in hochempfindlichen Peroxidase-Bestimmungen für „Enzyme Linked Immunoadsorbent Assay"}

Zusammenfassung: Die meisten der gebräuchlichen enzym-immunologischen Bestimmungen verwenden MeerrettichPeroxidase als Markerenzym. Hier wird der Einsatz von ABTS (2,2'Azino-di-(3-ethyl benzthiazolin-6-sulfonsäure) als Chromogen zur Darstellung von geringen Mengen gebundener Peroxidase mit dem Einsatz von Trinder's Reagenz verglichen.

Die Bildung von Chromophoren bei der Benutzung von Trinder's Reaganz unter den von Gallati (J. Clin. Chem. Clin. Biochem. (1977) 15, 699-703) beschriebenen Bedingungen kommt nach 3-4 Stunden infolge der durch $\mathrm{H}_{2} \mathrm{O}_{2}$ induzierten Inaktivierung des Enzyms zum Stillstand. Im Gegensatz dazu führt der Einsatz vor. $\mathrm{H}_{2} \mathrm{O}_{2}$ - und ABTS-Konzentrationen und von Temperaturbedingungen, wie sie hier beschrieben werden, im selben System zu einer Chromophorproduktion, die bis zu 20 Stunden andauert.

Der Einsatz von ABTS/ $\mathrm{H}_{2} \mathrm{O}_{2}$ als Substrat in einem ELISA-Test für Antikörper gegen basisches Myelinprotein, wie er hier beschrieben ist, ergibt ein Testsystem, das 14-fach empfindlicher ist als ein vergleichbares, optimal mit Trinder's Reagenz arbeitendes System.

\section{Introduiction}

Enzyme linked immunoadsorbent assays (ELISA) have found a wide usage (1). Their many advantages over radioimmunoassay include convenience and the longer shelf life of reagents (1). Providing that the reaction conditions are optimised the sensitivity obtained by ELISA may approach that of radioimmunoassay (1). Óne key factor which determines ELISA sensitivity is the sensitivity of the final enzyme assay stage.
The widespread use of horse radish peroxidase (EC 1.11.1.7) as marker enzyme results from its high turnover number, high stability and ease of coupling to antigens, antibodies and protein $A(1,4)$. Early chromogens for the detection of peroxidase were insensitive and many were suspected carcinogens (2). ABTS (2,2'-azino-di-(3-ethyl benzthiazoline-6sulphonic acid), which has no known carcinogenic properties has recently been used successfully in some enzyme immunoassays (1). 
Problems are encountered when attempts are made to extend peroxidase assays for long periods to increase sensitivity (3). Peroxidase is slowly converted by its substrate $\mathrm{H}_{2} \mathrm{O}_{2}$ into an enzymically inactive form (3). Gallati (3) has proposed the use of Trinder reagent as a chromogen for the detection of small amounts of peroxidase. He claimed to have defined reaction conditions where inactivation of the enzyme was reduced. However, Gallati presented no absolute data on sensitivity (3). No comparison was made with any other chromogen. Furthermore, the Trinder assay conditions (3) were not tested on an actual ELISA.

In the present work some of the factors affecting the time course of peroxidase assays were studied. Conditions are described, whereby the peroxidase reaction using ABTS as chromogen, can be made to continue for $20 \mathrm{~h}$ and beyond.

The ABTS based assay for peroxidase was then compared with Trinder reagent in an enzyme immunoassay for antibodies to myelin basic protein. The use of ABTS, as described, gave an assay at least 14 times more sensitive than the maximum obtainable with Trinder reagent.

These observations may be of some interest to those workers who require highly sensitive enzyme immuno. assays based on peroxidase.

\section{Materials and Methods}

Horse radish peroxidase (Grade 1) and ABTS were obtained from Boehringer, Mannheim, GmbH, West Germany.

Goat antirabbit IgG/peroxidase conjugate was obtained from Miles UK Ltd., Stoke Court, Slough, Berks, U.K.

4-amino-antipyrine was obtained from the Aldrich Chemical Co. Ltd., Gillingham, Dorset, U.K.

Hydrogen peroxide and other laboratory chemicals of Analytical Grade were obtained from BDH Chemicals, Poole, Dorset, U.K.

\section{Peroxidase assays}

All peroxidase assays were carried out in $0.1 \mathrm{~mol} / 1$ phosphate buffer $\mathrm{pH}$ 7.0. Reactions were initiated by the addition of 10 $\mu l$ of an appropriate enzyme dilution to $1 \mathrm{ml}$ of substrate solution. All dilutions of enzyme were made in $0.1 \mathrm{~mol} / 1$ phosphate buffer $\mathrm{pH} 7.0$ containing $10 \mathrm{~g} / 1$ bovine serum albumin. ABTS was used at a concentration of $1.8 \mathrm{~mol} / \mathrm{l}$ throughout.

Trinder reagent was used as described by Gallati (3).

\section{ELISA for antibodies to myelin basic protein}

Bovine myelin basic protein was used to coat disposable polystyrene tubes. The tubes, containing $1 \mathrm{ml}$ amounts of various dilutions of a rabbit antiserum to myelin basic protein were then incubated for $16 \mathrm{~h}$ to allow antibody attachment. Bound rabbit IgG was detected by further incubation in the presence of a goat-antirabbit IgG/peroxidase conjugate, followed by peroxidase assay. $1 \mathrm{ml}$ of the appropriate substrate solution was added to each tube and the tubes were incubated for $20 \mathrm{~h}$ at $20^{\circ} \mathrm{C}$ in a shaking water bath. The absorbance values at $420 \mathrm{~nm}$ were read against an appropriate blank. Full details of this ELISA for antibodies to myelin basic protein will be described in a further communication.

\section{Results}

\section{Kinetics of chromophore production using Trinder reagent and $A B T S$}

Figure 1a shows the time course of colour production when a small amount of peroxidase (peroxidase conjugated goat antirabbit $\mathrm{IgG}$ ) was incubated with $\mathrm{H}_{2} \mathrm{O}_{2}$ / Trinder reagent at $37^{\circ} \mathrm{C}$. Conditions were as described by Gallati (3). The absorbance at $492 \mathrm{~nm}$ reached a plateau after 3-4 h. It then remained constant for long periods. This cessation of enzyme action is due to the formation of an enzymically inactive complex between peroxidase and its substrate $\mathrm{H}_{2} \mathrm{O}_{2}$ (3).

Figure $1 \mathrm{a}$ also shows a time course for the same amount of peroxidase, using the same $\mathrm{H}_{2} \mathrm{O}_{2}$ concentration $(0.8$ $\mathrm{mmol} / \mathrm{l}$ ) but replacing the Trinder reagent with 1.8 mmol/1 ABTS. A similar cessation of enzyme activity takes place as observed with the Trinder reagent. In the reaction with $\mathrm{ABTS}$, however, the chromophore is unstable due to a disproportionation reaction (5). Therefore the final absorbance at $420 \mathrm{~nm}$ slowly decreases on further incubation.

It was next decided to investigate the parameters affecting the time course of the peroxidase reaction, using $\mathrm{ABTS}$ as chromogen. This was to de termine whether the reaction could be made to continue over a longer period with a consequent increase in sensitivity.

\section{Effect of temperature on the time course of the peroxidase reaction}

Figure $1 \mathrm{~b}$ shows the time course of the ABTS and Trinder assays under similar conditions to figure 1 a but carried out at $20^{\circ} \mathrm{C}$ instead of $37^{\circ} \mathrm{C}$. Although the initial rates of reaction were reduced by lowering the temperature, enzyme action then continued over a longer period. This is because the temperature reduction has a greater effect in slowing inactivation of the enzyme by $\mathrm{H}_{2} \mathrm{O}_{2}$ than in slowing the rate of catalysis. The final absorbance at $420 \mathrm{~nm}$ at the plateau using ABTS as chromogen was twice the value at $20^{\circ} \mathrm{C}$ as at $37^{\circ} \mathrm{C}$.

To determine the optimum temperature at which to carry out at $20 \mathrm{~h}$ peroxidase assay several identical $\mathrm{ABTS} / \mathrm{H}_{2} \mathrm{O}_{2}$ substrate mixtures were placed at different temperatures and the reactions initiated by the addition of the same amount of peroxidase to each. The absorbance at $420 \mathrm{~nm}$ of each assay was read at various times against a blank which had been incubated at the same temperature (fig. 2). 


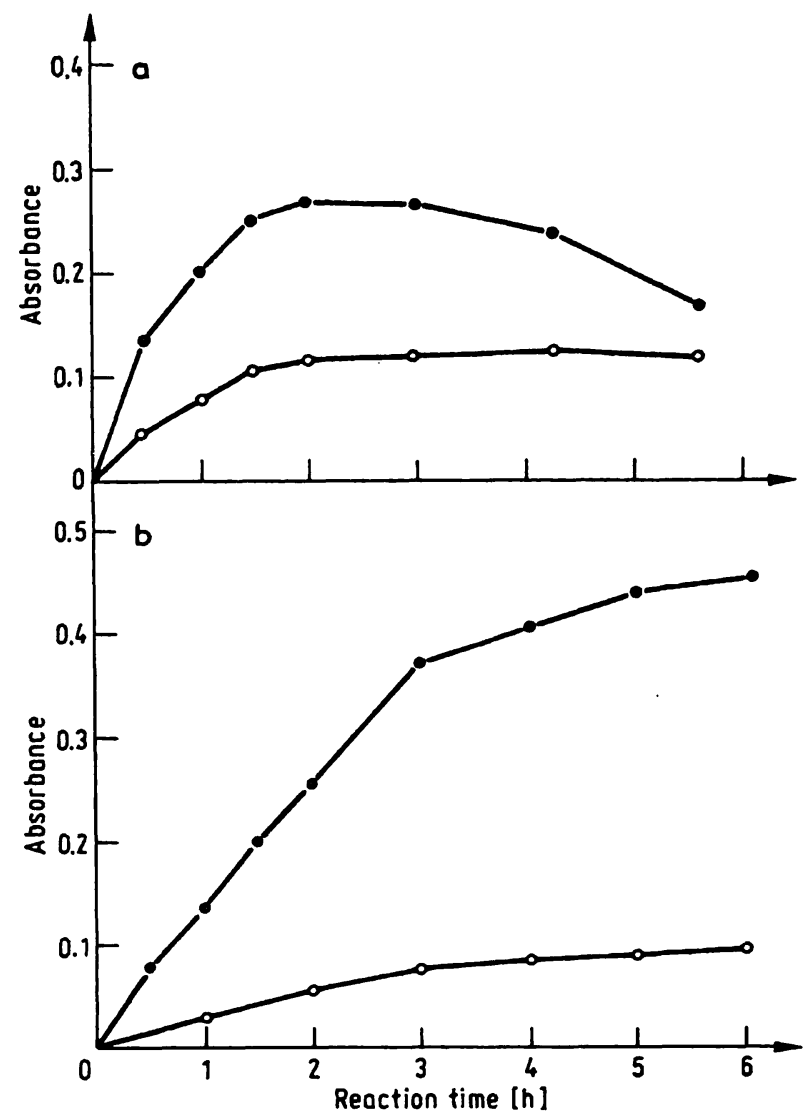

Fig. 1. Time course of peroxidase reaction at different temperatures.

a) at $37^{\circ} \mathrm{C}$

ABTS as chromogen, $\bullet-\bullet=$ absorbance at $420 \mathrm{~nm}: 1.8$ $\mathrm{mmol} / 1 \mathrm{ABTS}, 0.8 \mathrm{mmol} / 1 \mathrm{H}_{2} \mathrm{O}_{2}$ in $0.1 \mathrm{~mol} / 1$ phosphate buffer pH 7.0.

Trinder reagent as chromogen, $0-0=$ absorbance at $492 \mathrm{~nm}: 2 \mathrm{mmol} / 1$ 4-amino-antipyrine, $25 \mathrm{mmol} / 1$ phenol, $0.8 \mathrm{mmol} / 1 \mathrm{H}_{2} \mathrm{O}_{2}$ in $0.1 \mathrm{~mol} / 1$ phosphate buffer $\mathrm{pH} 7.0$ (3).

All assays contained the same amount of peroxidase (goat anti rabbit IgG/peroxidase conjugate).

As expected the initial rate of reaction was reduced as the temperature was lowered. The figures added to figure 2 indicate the final absorbances obtained after a total incubation time of $20 \mathrm{~h}$, and it is apparent that there is an optimum temperature at which to carry out the peroxidase assay for maximum sensitivity. Above $20^{\circ} \mathrm{C}, \mathrm{H}_{2} \mathrm{O}_{2}$ induced inactivation of the enzyme limits the final absorbance. Below $20^{\circ} \mathrm{C}$ although inactivation of the enzyme is reduced, this is offset by reduction in the intrinsic rate of catalysis.

Superimposed upon thèse effects will be any effects of temperature on the stability of the final ABTS chromophore. It is also possible that some loss of enzyme activity is due to simple thermal denaturation and not to reaction with $\mathrm{H}_{2} \mathrm{O}_{2}$. The present data did not permit a precise kinetic description of these complex events. They did, however, suggest that $20^{\circ} \mathrm{C}$ was close to the optimum temperature at which to carry out a $20 \mathrm{~h}$

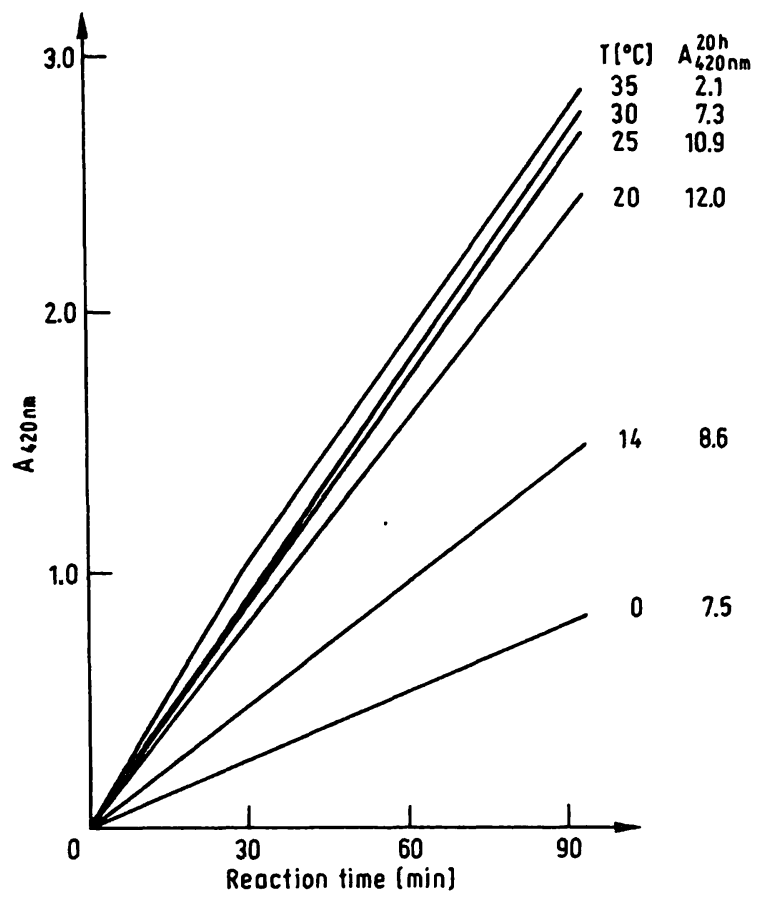

Fig. 2. Time course of peroxidase reaction at various temperatures. The temperatures are given in the first column; the second column indicates absorbance at $420 \mathrm{~nm}$ after a $20 \mathrm{~h}$ incubation (measured on a $10^{-1}$ dilution). 1.8 $\mathrm{mmol} / 1 \mathrm{ABTS}, 0.8 \mathrm{mmol} / 1 \mathrm{H}_{2} \mathrm{O}_{2}$ in $0.1 \mathrm{~mol} / 1$ phosphate buffer $\mathrm{pH}$ 7.0. All reactions were initiated with the same amount of peroxidase conjugated antibody.

peroxidase assay with ABTS. This temperature was therefore selected for routine use.

\section{Effect of $\mathrm{H}_{2} \mathrm{O}_{2}$ concentration on the time course of the peroxidase reaction}

$\mathrm{H}_{2} \mathrm{O}_{2}$ concentration was another variable whose reduction it was thought might further offset the inactivation of the enzyme. Figure 3 shows that raising the concentration of $\mathrm{H}_{2} \mathrm{O}_{2}$ above $0.8 \mathrm{~mol} / 1$ resulted in accelerated destruction of the enzyme. Reduction of the $\mathrm{H}_{2} \mathrm{O}_{2}$ concentration to $0.4 \mathrm{mmol} / 1$ and $0.2 \mathrm{mmol} / 1$ resulted in reactions where colour production continued for $17 \mathrm{~h}$ and beyond. At $0.1 \mathrm{mmol} / 1 \mathrm{H}_{2} \mathrm{O}_{2}$ the reaction again appeared to plateau prematurely. This was assumed now to be due to depletion of substrate.

This experiment showed clearly that reduction in $\mathrm{H}_{2} \mathrm{O}_{2}$ concentration prolongs the peroxidase reaction. To determine whether this observation could be put to some practical purpose it was thought necessary to test the $\mathrm{ABTS} / \mathrm{H}_{2} \mathrm{O}_{2}$ assay conditions on an authentic enzyme linked immuno-adsorbent assay.

Effect of $\mathrm{H}_{2} \mathrm{O}_{2}$ concentration on the sensitivity of an enzyme linked immunoadsorbent assay (ELISA)

The ELISA used was an assay for rabbit antibodies to bovine myelin basic protein. Conditions of the assay are 


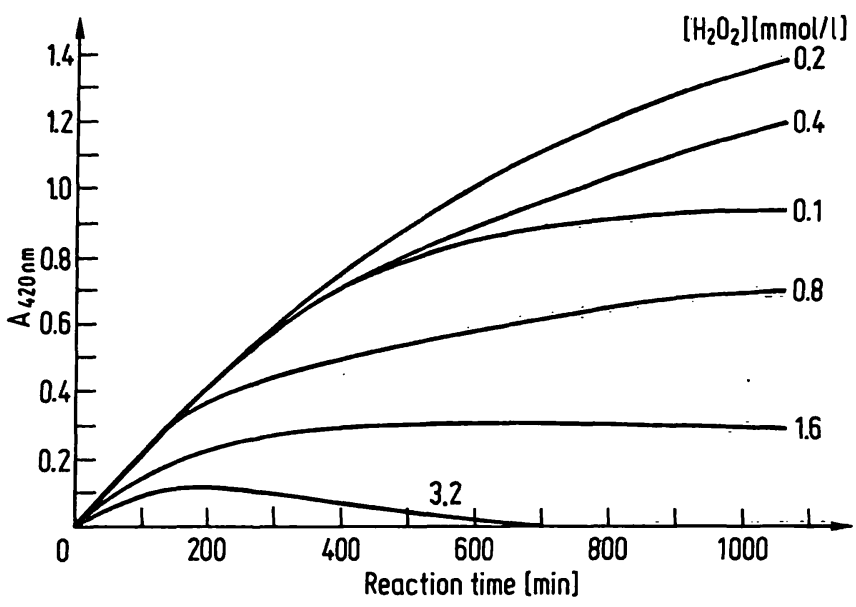

Fig. 3. Time course of peroxidase reaction at various $\mathrm{H}_{2} \mathrm{O}_{2}$ concentrations.

ABTS concentration $1.8 \mathrm{mmol} / 1$ in $0.1 \mathrm{~mol} / 1$ phosphate buffer $\mathrm{pH}$ 7.0.

All reactions were initiated with the same amount of peroxidase conjugated antibody.

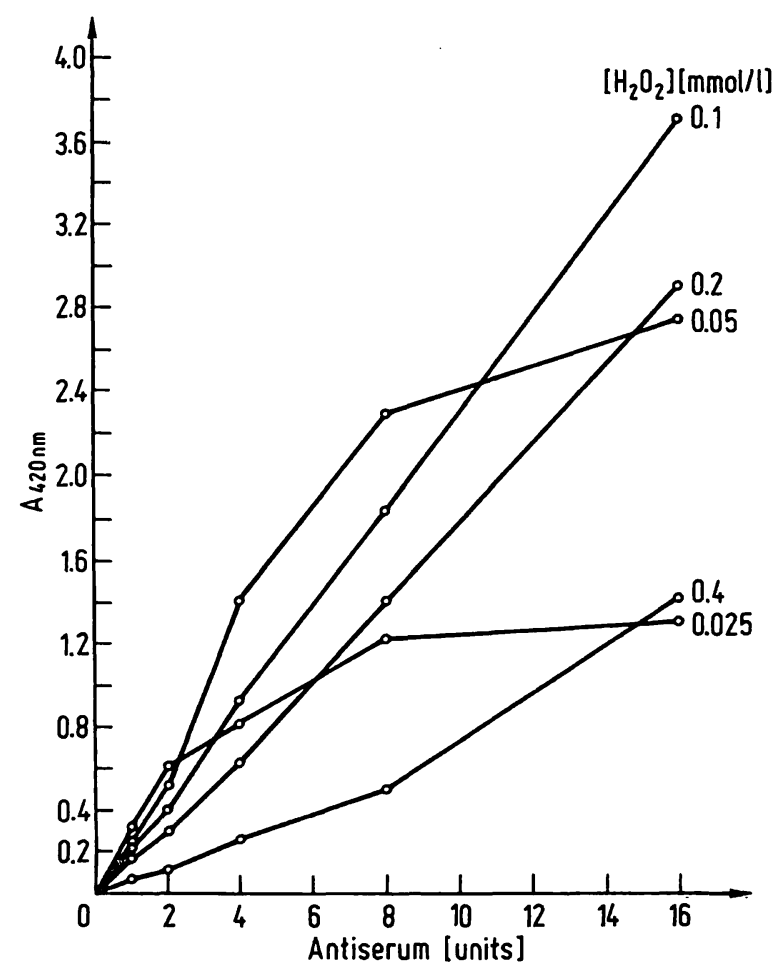

Fig. 4. Effects of $\mathrm{H}_{2} \mathrm{O}_{2}$ concentration on an ELISA for rabbit antibodies to bovine myelin basic protein. Procedure as described in "Methods". 1 unit of antiserum is defined as $1 \mathrm{ml}$ of a 1 in 256000 dilution of reference anti MBP serum KK42. The final peroxidase assay is initiated by adding $1 \mathrm{ml}$ of substrate solution to each tube. The tubes are then incubated for $20 \mathrm{~h}$ at $20^{\circ} \mathrm{C}$ in a shaking water bath before reading the absorbance at $420 \mathrm{~nm}$. The substrate solutions contained $1.8 \mathrm{mmol} / 1 \mathrm{ABTS}$ in $0.1 \mathrm{~mol} / 1$ phosphate buffer $\mathrm{pH} 7.0$ supplemented with different amounts of $\mathrm{H}_{2} \mathrm{O}_{2}$.

described briefly in 'Methods'. The experiment (fig. 4) shows that the relationship between absorbance and the amount of antibody is complex and very dependent on $\mathrm{H}_{2} \mathrm{O}_{2}$ concentration, as expected.
Although the sensitivity at 2 units of antiserum gradually increases as the $\mathrm{H}_{2} \mathrm{O}_{2}$ concentration is reduced even down to $0.025 \mathrm{mmol} / \mathrm{l}$ the range of the assay is then restricted by $\mathrm{H}_{2} \mathrm{O}_{2}$ depletion at the higher peroxidase activities associated with more antiserum. The $\mathrm{H}_{2} \mathrm{O}_{2}$ concentration which gave the closest approximate to a linear relationship between absorbance and antiserum amount up to an absorbance at $420 \mathrm{~nm}=1.0$ was 0.1 $\mathrm{mmol} / 1 \mathrm{H}_{2} \mathrm{O}_{2}$. Subsequent experiments have shown that the relationship between absorbance and antiserum amount for $0.1 \mathrm{mmol} / 1 \mathrm{H}_{2} \mathrm{O}_{2}$ is slightly non linear, with a tendency for the graph to cuive towards the absorbance axis.

\section{Comparison of sensitivity obtainable with ABTS and Trinder reagent}

Gallati has presented the Trinder reagent as a chromogen for the detection of the small amounts of peroxidase as required in ELISA (3). It appeared likely that the ABTS assay devised here was many times more sensitive than possible with the Trinder reagent.

Figure 5 shows two identical ELISA titrations where the only difference is the final peroxidase assay. One uses Trinder reagent and the conditions described by Gallati (3). The other uses $1.8 \mathrm{mmol} / 1 \mathrm{ABTS} 0.1 \mathrm{mmol} / 1$ $\mathrm{H}_{2} \mathrm{O}_{2}$ in $0.1 \mathrm{~mol} / 1$ phosphate buffer $\mathrm{pH} 7.0$ at $20^{\circ} \mathrm{C}$ for $20 \mathrm{~h}$. These were the conditions found to be optimal in the present study.

The latter assay was 14 times more sensitive than that published by Gallati.

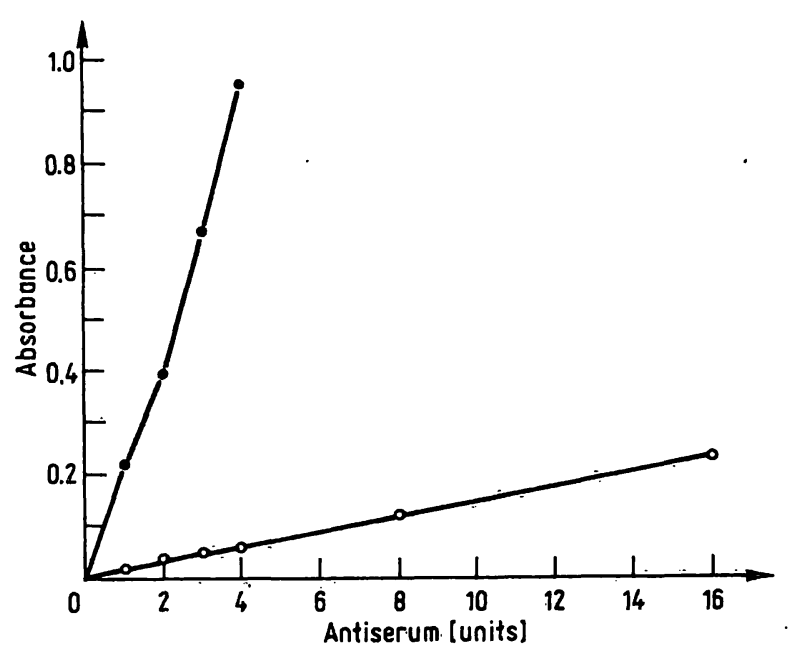

Fig. 5. A comparison of ELISA sensitivity using Trinder reagent and ABTS as chromogens. Assay for antibodies to myelin basic protein as in figure 4 .

ABTS: $1.8 \mathrm{mmol} / 1 \mathrm{ABTS}, 0.1 \mathrm{mmol} / 1 \mathrm{H}_{2} \mathrm{O}_{2}$ in $0.1 \mathrm{~mol} / 1$ - phosphate buffer pH 7.0.20 ${ }^{\circ} \mathrm{C}$ for $20 \mathrm{~h}$, $\longrightarrow=$ absorbance at $420 \mathrm{~nm}$.

Trinder: $2 \mathrm{mmol} / 1$ 4-amino-antipyrine, $25 \mathrm{mmol} / 1$ phenol, $0.8 \mathrm{mmol} / 1 \mathrm{H}_{2} \mathrm{O}_{2}$ in $0.1 \mathrm{~mol} / 1$ phosphate buffer pH 7.0. $37^{\circ} \mathrm{C}$ for $6 \mathrm{~h}, \mathrm{o}-\mathrm{o}=\mathrm{absorbance}$ at $492 \mathrm{~nm}$. 


\section{Absolute sensitivity of the peroxidase assay}

Various known amounts of purified horse radish peroxidase were incubated with $\mathrm{ABTS} / \mathrm{H}_{2} \mathrm{O}_{2}$ as described above. The absorbances at $420 \mathrm{~nm}$ after $20 \mathrm{~h}$ were read against a suitable blank. Figure 6 shows a concave form similar to that found in the ELISA of figure 4 and figure 5. This suggests that the concave relationship is due to the complexity of the kinetic reaction and is independent of whether the peroxidase is in solution or solid phase. Since an absorbance of 0.02 is still measurable against a low blank this assay should be capable of detecting $0.02 \mathrm{ng}$ of peroxidase.

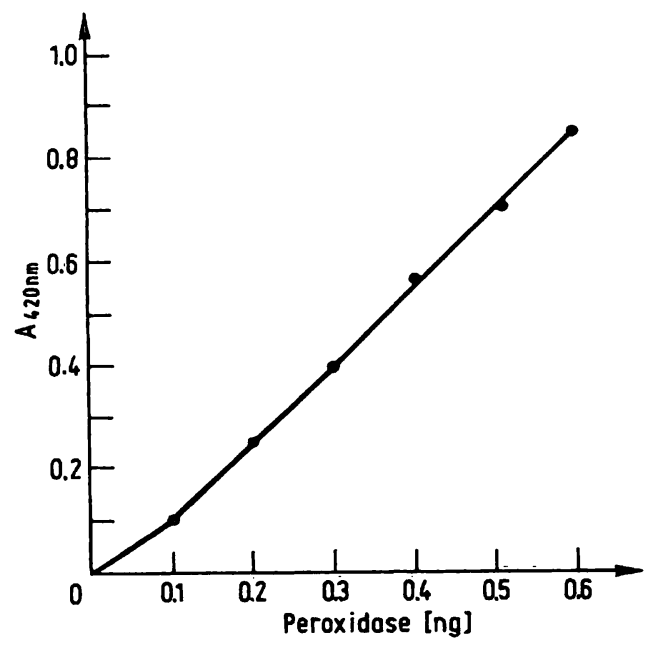

Fig. 6. Relationship between absorbance and amount of peroxidase. Peroxidase (Boehringer Type 1) was added to $1 \mathrm{ml}$ volumes of substrate mix ture; $1.8 \mathrm{mmol} / 1 \mathrm{ABTS}$, $0.1 \mathrm{mmol} / 1 \mathrm{H}_{2} \mathrm{O}_{2}$ in $0.1 \mathrm{~mol} / 1$ phosphate buffer $\mathrm{pH} \mathrm{7.0}$. Tubes were incubated at $20^{\circ} \mathrm{C}$ in a shaking water bath for $20 \mathrm{~h}$ before reading the absorbances at $420 \mathrm{~nm}$ against a blank.

\section{Discussion}

These experiments were stimulated by the need to develop a highly sensitive assay for solid phase peroxidase. No references could be found to peroxidase

\section{References}

1. Schuurs, A. H. W. M. \& Van Weemen, B. K. (1977) Clin. Chim. Acta 81, 1-40.

2. Childs, R. E. \& Bardsley, W. G. (1975) Biochem. J. 145, 93-103.

3. Gallati, by H. (1977) J. Clin. Chemm. Clin. Biochem. 15, 6.99-703.

4. Dubois-Dalcq, M., McFarland, M. \& McFarlin, D. (1977) J. Histochem. Cytochem. 25, 1201-1206. assays where the reaction had been extended beyond one hour. When attempts were made to use ABTS for long term assay the reaction immediately became apparent.

Systematic variation of temperature and $\mathrm{H}_{2} \mathrm{O}_{2}$ concentration have defined condition where the peroxidase reaction continues for long periods. The conditions described here were tested in an ELISA for antibodies to myelin basic protein and found to give an assay at least 14 times more sensitive than that obtainable with Trinder reagent (3).

The enzyme linked immunoadsorbent assay for rabbit antibodies described here uses peroxidase conjugated to antirabbit IgG as the detection reagent. If one makes several assumptions it is possible to calculate the minimum amount of rabbit IgG detectable by such a procedure using the $\mathrm{ABTS} / \mathrm{H}_{2} \mathrm{O}_{2}$ peroxidase assays. These assumptions are:

1. That the first antibody has at least 5 antigenic determinants accessible to second antibody and that these can be occupied simultaneously in the presence of excess second antibody (6).

2 . The second antibody is conjugated to peroxidase in a 1:1 molar ratio (7).

3. The conjugated peroxidase retains its full enzyme activity (7).

Making these assumptions it can be calculated that with the present peroxidase assay an absorbance of 0.02 would correspond to $0.015 \mathrm{ng}$ of rabbit IgG.

\section{Acknowledgement}

The author wishes to thank Dr. David Fell of Oxford Polytechnic for advice and criticism of the manuscript, Mrs. B. Hammon of Oxford Polytechnic and Dr. Surholt of Oxford University for translations.

Dr. W. Palfreyman of the Biochemistry Department, Royal Infirmary, Glasgow, provided the antiserum to myelin basic protein (KK42).

5. Werner, W., Riechmann, P., Rey, H. G., Wielinger, H., Kahle, K., Weiss, L., Klarwein, M. \& Wieland, O. (1971) Quad. Sclavo. Diagn. 7, 231-242.

6. Davis, D., Dulbecco, R., Eisen, H. N., Ginsberg, H. S. $\&$ Wood, W. B. (1967) Principles of microbiology and Immunology, p. 383. Harper and Row, N.Y.

7. Nakane, P. K. \& Kawaoi, A. (1974), J. Histochem, Cytochem. 22, 1084-1090.

N. P. Groome, M. Sc., Ph. D.

Dept. Biology

Oxford Polytechnic

Headington

Oxford OX 30 BP 
. 